\title{
SOME REFLECTIONS ON THE ECONOMIC CONSEQUENCES OF THE CANCELLATION OF A CONTRACT IN FRENCH LAW
}

Yves-Louis Sage and Anthony H Angelo**

French law has no general rules on restitution. However, it does have specific restitutionary principles for different areas of law. This article, originally written in French, considers the restitutionary principles that apply in the field of contract.

\section{INTRODUCTION}

The Court of Cassation has stated the principle: ${ }^{1}$ a contract that is cancelled ceases to have effect for the future; the cancelling of the contract results in the retroactive voiding of the effects of the contract and therefore the parties cannot demand fulfilment of obligations which have not yet been effected, but retain the right to have any performance that has been given restored; this creates a sort of reverse synallagamatic ${ }^{2}$ contract which obliges the parties to return the performance received.

Theory and case law agree that this statement of principle presents few difficulties and that the parties must be restored to the position they were in at the time they made the contract.

* Maître de Conférences, Université de Polynésie Française; Teaching Fellow, Massey University.

** Professor of Law, Victoria University of Wellington.

1 See for example, Cass Civ 1er, 22 July 1987: Bull civ 1, $n^{\circ} 252$ refusal to order payment to go-between in an illegal adoption.

2 J Carbonnier Droit civil, $\mathrm{T} 4 \mathrm{n}^{\circ} 49$. 
However, there remain numerous difficulties with the principle at a practical level, particularly when dealing with the consequences of the cancelling of a contract retrospectively.

Furthermore the retroactive cancellation of a contract does not mean that the contract can never be the basis of a legal action, ${ }^{3}$ because each of the parties ${ }^{4}$ to the contract can plead against the other the exception of non-performance and thereby suspend their own restoration of any performance received until after that of the other party. ${ }^{5}$

This said, certain factors are constant: primarily cancellation requires the restoration in kind of the whole performance received.

\section{PRINCIPLE OF TOTAL RESTITUTION IN KIND}

The restitution can relate to a thing or to a service and each of these situations generates different consequences. Moreover the value of the thing which was the object of the contract may have changed, which may affect the amount of the restitution.

\section{A The Primary Obligation Relates to a Thing}

There is here an almost perfect match with the rules provided by French law relating to revindication (restoration of property). ${ }^{6}$

Thus, so long as restitution in kind is possible the creditor may, subject to there being a real interest in the property for the creditor, ${ }^{7}$ demand restitution in kind and refuse any offer of restitution by way of value.

3 Cass Civ ler, 14 October 1975 pourvoi n 74-12.120: Juris-Data. $n^{\circ}$ 75-10264: 4 May 1982: Lexis. $n^{\circ} 431$ : Bull civ $1 n^{\circ} 154$.

4 Restitution must take place between the parties to the cancelled contract (and not for the benefit of related contractors such as lenders or guarantors); Cass Com 17 December 1980: Bull civ IV n 433.

5 Cass Com 21 July 1975: D 1976, p 582 note Agostini and Diener.

6 Ph Malaurie et L Aynes Droit civil, Obligations (éd Cujas, 1985) nº 376.

7 Otherwise, demanding restitution in kind can amount to an abus de droit, notably if restitution in kind is very onerous for the debtor and the creditor has no interest in that. Pau 15 February 1973: 3CP 1979 II. 17584. note JB: Paris, 5' Ch C, 28 February 1985: Gaz Pal 1985, 2.441. The Conseil de la Concurrence instructed petrol companies to renegotiate this aspect of their contracts because the clause "could have the effect of restricting competition in the market for petroleum products": decision 29 September 1987: BOCC, $\mathrm{p}$ 304. In its judgment of 16 February 1988, the Court of Cassation did not share this point of view. 
Case law has accepted this solution even when restitution in kind is particularly difficult. ${ }^{8}$

By preference, the restitution relates to the identical thing. As far as possible the thing will be returned in the condition that it was on the day of the contract: the cost of restoring it to that condition is therefore a charge on the debtor. ${ }^{9}$ It must equally be noted that any depreciation between the date of the contract and of restitution is a charge on the debtor. ${ }^{10}$

For expenses incurred since the making of the contract, article 555 of the Civil Code and the theory of expenses requires that the debtor must, on the basis of unjust enrichment, be indemnified for all useful expenditure to improve the thing.

\section{B The Obligation Relates to a Service}

The principle of restitution in kind does not present any difficulties at a practical level in respect of monetary performance.

However, the case law has sometimes admitted that sums of money paid in the application of a null indexation clause cannot be returned because in that case spontaneous payment amounted to a confirmation of the contract; ${ }^{11}$ or that the transaction was possible for the subject-matter; ${ }^{12}$ also because the payment had an illicit character which is outside the rules of restitution. ${ }^{13}$

Restitution in kind is in general impossible for non-monetary performance. In such cases the judges have looked to a method of restitution by equivalence.

Where a contract with successive stages of execution has been cancelled, performance already given cannot be restored in kind. The monetary counterpart is assessed on an

8 Cass Com 17 November 1982: JCP 1984,II. 20216. note Delebecque and Mouly. 29 January 1985 : Bull civ IV n 43 : Paris 29 March 1985: Gaz Pal 1985, 2, 544: Rev trim dr civ 1985734 nº 1, obs Rémy; Cass Com 29 January 1985: Bull civ IV n 43: 16 February 1988: Lamy Droit économique Mise à jour 1988, $\mathrm{n}^{\circ}$ 3448.

9 Cass Civ l, 2 June 1987: Bull civ 1. n 183: Rev trim dr civ 1988. 528, obs Mestre.

10 Cass Com 11 May 1976: Bull civ IV n 162: Defrénois 1977 art 31343 obs Aubert.

11 Toulouse, 3 March 1975: D, 1975, 772; JCP 1975 II 18034.

12 Cass Civ 323 October 1975: Bull civ III n 310.

13 Cass Civ III 12 June 1979: JCP 198111 19494. 2 ieme esp, note Boyer; Rev trim dr civ 1981,155, obs Chabas Contra Cass Civ 3, 8 December 1981: Bull civ 111, n² 203; D 1982. Inf rap 469 obs Magnin. 
equitable basis. Thus when a employment contract is cancelled the employer must indemnify the worker for the work provided; ${ }^{14}$ in the cancelling of a lease the tenant must give the landlord an occupation indemnity; ${ }^{15}$ the cancellation of a contract for agricultural integration carries with it the obligation to return to the farmer the value of the performance given "by way of penalties and charges directly linked to the execution of the annulled contract". ${ }^{16}$

Restitution by equivalence must sometimes be limited to what is necessary to assure a return to the status quo ante. Thus the Court of Cassation has denied approval to any decision which values the restitution by taking account of the benefit and losses that came from the annulled contract because that amounts to giving effect to cancelled contracts. Consequently the relationship of the parties after the cancellation cannot be determined in accordance with the rules for de facto partnerships but must give rise to the establishment of a restitution account. $^{17}$

\section{Variations in the Value of the Thing to be Restored}

There is necessarily some time between the conclusion of the contract, its cancellation and effective restitution. The value of the object to be restored is therefore affected either positively by an increase in value or because it has generated income or negatively by a loss in value.

If the restitution relates beyond the thing itself to the revenue or product of the thing since the date of the contract, the debtor does not have to give the creditor restitution of an amount equal to the profit which the creditor would have obtained from the use of the thing. ${ }^{18}$

14 For example Cass Soc 8 avril 1957: D 1958. 221. note Malaurie: 22 November 1979: Bull civ V, n 885; D 1980. Inf rap p 258: 3 October 1980: Bull civ V, n 704, D. 1982. 708. note Agostini: Rev trim dr civ 1982. 419, obs Chabas. Restitution is sometimes based on the unjust enrichment of the employer. Cass Soc. 15 February 1978: Bull civ V. n 107; D. 1980. 1er esp. p 30. note G Lyon-Caen.

15 Cass Civ 3. 1 July 1987: Bull civ 111. n 134.

16 Cass Civ 1. 25 November 1981. D 1982. chr $219: 8$ December 1987: Bull civ 1, n 325: Rev trim dr civ 1988. 530. obs Mestre. V J Danet and L Lorvellec, art cit D 1982. p 211.

17 Cass Civ 1. 4 November 1986: Bull civ 1. n²47, and 3 February 1987: Bull civ 111. n 37.

18 Cass Com, 11 May 1976: Bull civ IV. n 162: Defrénois 1977 art 31343. p 393. obs Aubert: Cass Civ lre. 2 June 1987. 


\section{Increases in value}

Increases in value can have material causes, which are generally attributable to one of the contracting parties: increases and improvements, or reasons of an economic or fortuitous nature. It seems logical to allow the benefit of these increases which are inherent in the thing to go to the party who takes the goods after the annulling of the contract and who is deemed to have always been the owner.

The courts have had very little to do with increases in value. As far as the increase in value of immovable properties is concerned, article 555 of the Civil Code must apply. A builder in good faith, here the party who must give up the immovable, has a right to an indemnity equal either to the value by which the land has increased, or to the expenses incurred valued at the date of reimbursement. A bad faith builder may be required to demolish the building, but there is no case law yet on this point.

On the other hand the question has been asked of the Court in Paris about the similar hypothesis of the annulling of a sale of interests in a construction company. ${ }^{19}$ The rights of partners are movable by nature and article 555 of the Civil Code is not applicable. However, the seller cannot have restitution of these interests without taking account and acknowledging to the debtor the increase in their value due to the construction made by the debtor.

The indemnity will be calculated according to the traditional rules for the action de in rem verso, the indemnity being equal either to the impoverishment on the day it occurred or the enrichment on the day of the claim. This solution is accepted by a substantial number of writers in relation to unjust enrichment. It is explained by the idea of a debt of value. Restitution does not relate to the sums of money provided by the purchaser of interests in the company but to the value of the constructions that they have made it possible to build. The right to indemnity is attached to the construction and must be established in relation to the value, on the day judgment is given, of the construction to which the interests acquired in the company give rise.

The theory of expenses is applied to any increase in the value of immovable property (improvements are traditionally distinguished from constructions despite the criticism of several authors). ${ }^{20}$

19 Paris 22 November 1972, D 1974.93, note Malaurie.

20 Cass Civ 1,16 October 1979: Gaz Pal 1980.1, somm p 16, concerning the cost for restoring a picture. 
Any person who must return a thing, an acquirer in particular, has a right to full reimbursement of necessary expenses which have been incurred for the conservation of the thing. Maintenance expenses, which it is customary to pay from the income earned by the thing belong to the possessor in good faith who is also entitled to keep the income.

Useful expenses which were not absolutely necessary for the conservation of the land but which have increased its value give rise to an indemnity for the benefit of the person who must give up the thing. By drawing on the principles in articles 861, 1673 and 2175 of the Civil Code the indemnity is equal to the increase in value in the immovable as at the date of restitution. ${ }^{21}$

As far as movable property is concerned it seems a priori that reference can now be made only to the theory of unjust enrichment to indemnify the person who must give up the article, for the necessary and useful expenses. The indemnity here is equal to the smaller of the enrichment or the impoverishment. ${ }^{22}$

Traditionally it was considered that the impoverishment was to be valued by reference to the sum disbursed and the enrichment by the amount by which the patrimony of the other party was increased at the date of the claim for restitution.

There is little case law on the point. A judgment of the First Civil Chamber of the Court of Cassation of 18 January $1960^{23}$ decided that the date of the claim should be used both in valuing the impoverishment and the enrichment.

Theorists for their part claim, by reference to the notion of the debt of value, that the impoverishment and the enrichment must both be valued at the day of judgment. ${ }^{24}$ The credit for the impoverished person is the value which passed into the patrimony of the enriched person.

21 Civ 3e, 23 March 1968, Bull civ III, n 138, p108.

22 Civ 1re, 19 January 1953, D 1953.234, and more recently Civ lre, 15 February 1973 D 1975.509, note R Savatier; Rép Defrénois 1975 art 30.858, 15 December 1976, Bull civ I, nº 408, p319 - Rép Defrénois 1977, art 31.522, obs Aubert, D 1977.IR150.

23 D 1960.753, note Esmein, S 1960.1.213; JCP 1961. II.11994, note Goré, Civ 15 December 1973.

24 Aubry et Rau by Dejean de la Batie, $\S 442$ ter, $\mathrm{n}^{\circ}$ 824; Carbonnier, $\mathrm{t} 4, \mathrm{p} 451$, Durand La dette de valeur thèse 1972, 403 - 408, Esmein, note D 196d.753; Malaurie, Cours de doctorat 1973-1974, 135; Marty et Raynaud, Les obligations, t 2, n 355, Raynaud, "Les dettes de valeur en droit français", Mélanges Brèthe de la Gressaye nS 18-19; Pierre-François La notion de dette de valeur en droit civil (thèse 1972) 107 s; Starck Les Obligations n 2307. 
However, although reference to the law on unjust enrichment would constrain the valuation, reference may be made to the rules for restitution which takes place after cancellation. Return to the status quo ante implies that the person who must restore the thing should be indemnified for their expenses. This obligation is a debt of value, even in the case of movables, since it is calculated on the increase in value of the thing.

\section{Decreases in value}

The object of restitution may have suffered a loss in value either for economic reasons - the decline in monetary value or obsolescence due to technological developments - or market shifts, or for material reasons - accidental damage, damage caused by one of the parties, wear and tear or old age.

When the depreciation is of a monetary nature (which is the usual case) the vendor must return the exact price which was received. There is no requirement to revalorise in order to compensate for inflation, because the debt is purely a monetary one and is not a debt of value.

On the other hand, obsolescence must be borne by the party to whom the thing is restored. That is to say, in the case of the nullity of a sale by the vendor who in effect is deemed to have always been the owner. It is true that if the thing had not been sold to this buyer the vendor would have been able, especially if a professional, to sell it to another person and therefore would not have borne the obsolescence.

The thing restored may have also deteriorated. When the deterioration is due to the fault of one of the parties the question is more one of liability than of restitution. The party at fault must compensate for the consequences of that fault. ${ }^{25}$ As a general rule when the article has deteriorated the debtor must indemnify the other party for this deterioration. ${ }^{26}$

25 Com 16 December 1975, Bull civ IV, n 308, p 256; See also Paris, 26 May 1972, JCP 1973.II.17419, note A S G.

26 The Commercial Chamber of the Court of Cassation quashed a judgment, which had required the vendor to carry the cost of deterioration by reference to the phrase res perit domino. Com 21 July 1975, D 1976.582, note Agostini and Diener. 
The solution is the same in relation to the wear and tear which must be taken into account in the calculation of the sum to be restored. ${ }^{27}$ Setting the value of the indemnities is at the discretion of the judge who will value them at the date of judgment. This resolves the problem, which arises from the erosion of value of money. The state of the thing at the date of the decision is compared with its state at the date of the contract.

There is one other element of depreciation with which the case law has not dealt directly, that is age. This is dealt with indirectly, in the case of restitution by way of value, by requiring the purchaser to carry the loss. It is submitted however that it is the creditor who should bear the cost of age for, if the contract had not been cancelled, the thing would have still have been the vendor's and the vendor would have suffered the effects of time.

\section{Restitution of revenues}

\section{(a) Article 547 of the Civil Code}

Under article 547 the fruits of a thing belong to its owner, and where a contract which has transferred title is cancelled the purchaser must, because the cancellation works retroactively, restore the fruits of the thing at the same time as the thing itself. But article 549 of the Civil Code modifies this rule in an important way; it allows the good faith possessor to keep the fruits.

According to the case law possessors who believe they are the owners will be in good faith if they are ignorant of the defects in the title by virtue of which they took possession of the thing. However, if they knew of the irregularity they must also hand over the fruits of the thing. 28

The reason is that the possessor believed he or she was authorised to deal with the fruits, and it is only a bad faith contractor who knows of the defects in title who should restore the

27 The Commercial Chamber quashed a judgment which had fixed the restitution in value of a vehicle, because restitution in kind was impossible, at a reduced figure because of the deprecation of the vehicle. Com 29 February 1972, above. See also Cass Com, 11 May 1976; Bull civ IV, n 162, p 137; Rép Defrénois 1977.393, obs Aubert; D 1976.1.R236. See below n 43.

28 Also a good faith possessor takes no profits from the date of the claim (Civ 3 May 1869, D 69.1.251; Civ 21 December 1926, DH 1927.84, Civ 1re, 1 February 1955, D 1955. Somm 76; Civ lre, 20 June 1967, D 1968.32; JCP 1967.II.15262, note JA); it does not necessarily become bad faith but the judgment has a declaratory character and it is necessary to determine the rights of the parties as at the date of notice of the claim. 
fruits of the thing (article 549 Civil Code) ${ }^{29}$ Consequently, interest on the restitution sum runs from the date of the order to pay and not from the return of the sum. ${ }^{30}$ Restitution relates only to the fruits which the thing would have produced in the state that it was in at the date of the contract. From the value of the fruits which are to be restored, all of the costs incurred for this produce must be deducted (article 548 Civil Code). If the value of the fruits arises solely from the activity of the debtor, case law allows the debtor to retain those fruits. ${ }^{31}$

In the situation where fruits are to be restored there is the problem of the costs incurred by the party bound to restore. This arises particularly in the case of immovable property.

The solution is found in article 548 of the Civil Code which provides that the fruits of the thing belong to the owner subject to a duty to reimburse for the cost of work, services, and sowing made by third persons, the value of which is known at the date of reimbursement. The scope of this rule is not limited to agricultural activities.

On the basis of this rule, theory and case law have developed two systems of original solutions. In the first system the possessor must restore all the fruits whether they have been produced by an immovable in its original condition or are a result of construction undertaken by the possessor. But the latter has the right to interest on the expenses incurred. ${ }^{32}$ This solution has been approved by the Court of Cassation ${ }^{33}$ on the basis that the revenue from a building in its original condition must be restored in total to the owner without any compensation for the interest.

In the second system the possessor must restore the fruits but has a right to retain that portion of them which is a product of his or her personal activity. In this case then there is a

29 Paris 22 November 1972: D 1974. 92. note Malaurie.

30 Cass Civ 3, 4 February 1981: Bull civ 111. n²4: Cass Civ 14 May 1982: Bull civ 1. n 154: Defrénois 1983. art 33082. p 785. ob Aubert.

31 Cass Civ 1, 20 June 1967: Bull civ 1. n 7; D 1968. 3; JCP 1967. 11. 15262 ; Rev trim dr civ 1968. 398. obs Bredin ; Cass Civ 1, 4 May 1982: Bull civ 1. n 15, Defrénois 1983, art 33082. n 51, p 785, note Aubert.

32 Aubry et Rau, t 2, 7e éd par Esmein, § 204, $\mathrm{n}^{\circ} 215$ for the bad faith possessor, see Demolombe, $\mathrm{t} 9, \mathrm{n}^{\circ}$ 679.

33 Civ 9 December 1839, S 40.1.66. See also, decision of 14 May 1957: the 1st Ch civ (see Aubry et Rau, above $\mathrm{n}$ 32) said, using the words of the appeal court, that "a possessor, even if in bad faith, who has to hand over profits, may claim from the owner interest on the cost of work that he has had done; the case involved the construction of a villa". 
separating of the fruits which derive from the thing in its original state and those which derive from the capital investment and work of the possessor. ${ }^{34}$ This solution was first apparent in a judgment of the Civil Chamber of 21 December $1903^{35}$ and picked up again in a judgment of the first Civil Chamber of 20 June 1967. ${ }^{36}$

\section{(b) Interest received on sums of money}

When the object of the restitution is not a thing but a sum of money, it produces interest.

The regime relevant to this is that of the repayment of sums not due (répétition de l'indu). Most writers consider that the cancelling of the contract relates to the field of repayment of sums not due ${ }^{37}$ and some judgments refer expressly to articles 1376 and following of the Civil Code. It flows from article 1378 that a person who receives money in bad faith must pay interest on the sums which have to be returned from the day on which they were received. On the other hand the acquirer in good faith may keep the interest earned before the date of the claim for restitution. ${ }^{38}$ This solution has the advantage of being in harmony with the solution used in relation to the fruits of the thing to be restored.

34 Aubry et Rau, t 2 7e éd par Esmein, $\S 206, n^{\circ} 225$ the good faith possessor; Demolombe, t 9, n S87; Planiol et Ripert, t 3, 2e éd par Picard, $n^{\circ} 364$.

35 D 1908.1.377. The court dismissed an appeal against a judgment which granted the production of a piece of land in its initial state to the owner and the production which resulted from improvements made by the possessor, to the possessor.

36 D 1968.32; JCP 1967.11.1S262, note J A; Rev trim dr civ 1968.337, note Bredin: "It follows from art 549 of the Civil Code that if the possessor has to give the profits to the owner, from the date of the restitutionary claim, the owner can claim only the profits that the thing would have produced in the condition in which it was when the possessor took possession". In the result the court quashed the judgment which had ordered the purchaser to hand over all the profits of an immovable, without distinction. Paris, 22 November 1972, D 1974.93, note Malaurie.

37 Ghestin, Encyclopedie Dalloz, Vo "Répétition de l'indu", $\mathrm{n}^{\circ} 17$ and the cases cited there.

38 Similarly, the Commercial Chamber decided (12 November 1979, Bull civ IV, no 286, p 227) that, following the cancellation of an exclusive supply contract between a brewer and a restauranteur, the restauranteur must deliver to the brewer the capital invested by the brewer plus interest on that money from the date when bad faith was established. This date was the date of a procedural document in which the restauranteur admitted that he had breached the contract. 
Even if the payment made under a contract which is later cancelled does not relate to the field of repayment of sums not due, ${ }^{39}$ interest on capital runs only from the day of the claim for restitution. ${ }^{40}$

\section{MODIFICATIONS TO THE RULE FOR TOTAL RESTITUTION IN KIND}

Although the principle of restitution in kind has general application, in practice cancelling of a contract does not always result in total restitution or a restitution in kind of performance. The situation in practice or a rule of law often are opposed to the application of this principle.

\section{A Material Limits}

Responding to the nullity of a contract often runs up against the practical impossibility of restoring a past performance, both in the case of things and services.

\section{When the performance related to a thing}

Total restitution cannot take place if the object in question has disappeared between the time of its delivery to the debtor and the cancelling of the contract. The consequences of the cancellation are governed differently depending on whether the possibility of restitution is or is not the fault of the debtor. Further, the thing to be restored may no longer be held by the other contracting party. It is necessary to distinguish several different possibilities.

\section{(a) The influence of the behaviour of the claimant for nullity}

It could be that the disappearance of the thing, which is the object of the contract, is the fault of the party who seeks nullity of the contract.

When restitution is impossible because of an act of the petitioner for nullity the court will sometimes declare that the action for nullity is non-receivable, at least in those cases where the debtor does not offer any guarantee of restitution in value. ${ }^{41}$ For example, when the petitioner has alienated the property and the acquirer is protected against revindication by article 2279 of the Civil Code or by usucapion. In this situation case law admits that an action for nullity is not

39 See Rodière, $\mathrm{t} 9$ bis, Traité de Beudant et Lerebours- Pigeonnière, $\mathrm{n}^{\circ} 1721$.

40 See Lobin "Le point de départ des intérêts légaux après une décision de condamnation" D 1978. Chron, p $12 \mathrm{~s}, \mathrm{n}^{\circ} 520 \mathrm{~s}$.

41 Cass Civ 17 December 1928: DH 1929; 52; Cass Civ 1, 23 December 1970: D 1970. 604, note Etesse: Cass Com 11 June 1981: Lexis nº 605. 
receivable. This has been decided particularly in the case of mutual exchanges where one of the parties has disposed of the immovable property received in the exchange. ${ }^{42}$

\section{(b) When the disappearance of the thing is not attributable to the party who seeks nullity}

When the disappearance of the thing is not attributable to the petitioner, nullity can be ordered. The restitution will then take place by way of value. The situation will be different when the property was bought on credit and resold by the unpaid vendor. ${ }^{43}$

There remains the situation of the thing which is lost by accident.

The first solution involves using the risk theory that was developed for situations of nonperformance of a contract so that the risk lies with the person who is to make the restitution which cannot be performed because of force majeure and, in contracts which transfer title, on the party who by reason of the retroactivity of nullity is deemed to have remained the owner. ${ }^{44}$

It is also relevant to ask how the value of the restitution should be determined. Logically it should include two indemnities, one equal to the value of the property on the day of its disappearance, and the other by way of compensation for any increased value of the property. It is easiest to assess this compensation globally. Three systems have been suggested.

(1) To make depreciation due to age a charge on the seller (which is quite normal) and also depreciation from use of the goods a charge on the seller (which is unfair because the purchaser has benefited from the use of the property); ${ }^{45}$

42 Civ 2 June 1886 DP 86.1.460; 17 December 1928, DH 1929.52. The $1^{\text {st }}$ Civil Chamber approved a decision which admitted an action to cancel a sale where "the thing sold retained its identity and special feataures". (Civ 1re, 23 February 1970, D 1970.604, note Etesse; Gaz Pal 1970.1.341; JCP 1970.11.16347, note P A). If the thing had been sold, destroyed or badly damaged, the claim would not have been admitted. Douai, 30 May 1949, D. 1949.592 note H L; Trib civ Seine, 22 May 1951, Gaz Pal. 1951.2.277).

43 This solution is implicit in two decisions of the Commercial Chamber, 29 February 1972 (D. 1972.623 ) and 18 November 1974 (D. 1975.625, note Malaurie) which settled the amount due without discussing the availability of the action.

44 The Court of Cassation seems to have used this analysis in relation to the nullity of a sale of animals. Cass Com, 21 July 1975, D. 1976.582, note Agostini.

45 In a case of cancellation of a credit sale of a car one Court of Appeal ordered restoration of the value as at the day of restitution ie the current value of a car of the same age, which takes account of normal wear and tear and loss of value (the Argus value). 
(2) The second system is the one favoured in the current case law. ${ }^{46}$ It involves reimbursing a sum equal to the value of the goods at the date of the contract distinguishing if necessary the true value of the thing from its price. ${ }^{47}$ In this system the purchaser bears the depreciation in value of the thing due to use and to ageing and the seller bears the losses due to the erosion of monetary values;

(3) The third system, the debt of value system, represents the debt as a sum in money determined, failing all else, by reference to the value of the property to which it is attached and this has been identified in the doctrinal writing. ${ }^{48}$

In this case the amount due to the purchaser is linked to the value that the thing which would have had to be returned and should be equal to the value of the property on the day of restitution in its condition at the date of sale. The purchaser thus bears the burden of use and of monetary depreciation and the seller that of age or obsolescence.

The theory was designed to provide a remedy for monetary depreciation, rather than for depreciation which results from use or ageing, in respect of goods whose value remains stable or increases. The technique of the debt of value is ill-adapted for consumer goods which depreciate in value rapidly. ${ }^{49}$

\section{(c) Cases of accidental disappearance of the thing to be restored}

The case law here applies the theory of risk but reverses it. ${ }^{50}$ Thus when a sale is cancelled the seller retroactively gains the status of owner and bears the risk of loss: restitution will be of the price received without restoration of the thing that has disappeared. ${ }^{51}$

46 See also Paris 31 October 1973, D. 1974.583, note Malaurie; Gaz Pal. 1974.1.283, note Brun.

47 This is the present position of the Commercial Chamber of the Court of Cassation (18 November 1974, D. 1975. 625, note Malaurie) and also adopted by the $1^{\text {st }}$ Civil Chamber, 12 December 1979; Francis Lefebvre Traité pratique de la fiscalité française, $12 \mathrm{e}$ éd, $\mathrm{n}^{\circ} 1282$.

48 Malaurie, notes D. 1974.583, D. 1975.625. Flour, "Pot-pourri autour d'un arrêt" Rép Defrénois 1975 p 145 s., spéc. p186; Flour et Aubert, Les obligations t. 2, nº 565.

49 It can produce an imbalance in the relationship of the parties since the debtor will not have to valorise the price.

50 Ph. Malaurie Cours de droit civil approfondi (Paris 1974-75) 169; A Sayag "La nullité des ventes non conformes à la réglementation du crédit" JCP 1972, 1, 2451.

51 Cass Civ 1", 6 December 1967: Bull civ 1, n 358; Rev trim dr civ 1968. 708. obs Chevallier: D. 1968, somm. p 37. Cass Civ 3', 24 November 1976, pourvoi n 75-13.076. 


\section{(d) The disappearance of the thing due to its having been consumed}

There is another possibility for restitution, which relates to the object of the contract. This flows from the consumable nature of the thing transferred and in such cases restitution is performed by way of equivalent. ${ }^{52}$

When restitution in kind is impossible because of the resale of the thing (or of any legal act which causes the thing to leave the patrimony of the debtor), the rule of return to the status quo ante leads to fixing the value for restitution at the date of the contract and not at the date of the restitution. There is therefore no reason to take account of depreciation due to use. ${ }^{53}$

\section{When the performance is a service}

This situation arises in respect of contracts, which have execution over time such as work contracts, letting contracts and partnership contracts. An employer cannot return the work provided by the employee nor the tenant the enjoyment of the thing lent. It is usual to say in respect of contracts of continuous execution that cancellation does not wipe out the performance already given.

In reality this results not from the fact that the contract has continuing execution but from the nature of the performance given which is usually an obligation to do something.

Two solutions have been suggested:

(1) The cancellation will have effect only for the future and all that is in the past will be governed by the contract. ${ }^{54}$

The legal relationship prior to the cancellation is governed by the contract except for substituting mandatory rules for those which have been contractually written. ${ }^{55}$

52 Civ 1re, 12 déc. 1979, JCP 1980.II.19464, note Prévault, D. 1980. I.R.390, obs Martine.

53 Cass Com 29 February 1972: D. 1972.623, 18 November 1974: D. 1975. 625. note Malaurie et Pans. 31 October 1973: D. 1974. 583. note Malaurie - account taken, on the date of restitution of the thing in its condition at the date of sale.

54 Flour et Aubert, Les obligations t. 1er, n³ 364; see also Malaurie, note D. 1958.221.

55 The employee will keep the salary and other benefits received, and the lender the rent received. Civ 3e, 9 May 1970, Bull civ Ill, $n^{\circ} 371$; p 269. A commercial company is wound up in accordance with its constitution (art 368 of Law of July 1966 and Cass, Crim. 1 February 1972, JCP 1972.II.17304, note Burst). 
This solution has the advantage of simplicity and certainty but is not consistent with the pattern of nullity which in principle means the denial of the effects to the contract.

(2) The contract, which has been cancelled, can produce no effect ${ }^{56}$ but account is taken of the situation which has been created in fact.

This situation generates ex-contractual obligations. The landlord will have the right to an occupation indemnity to compensate for the enjoyment that the tenant has had and the employee to an indemnity to compensate for the services from which the employer has profited. These indemnities are not necessarily equal to the rent or to the wage agreed. They will be fixed by the court, in what is sometimes a difficult operation. The case law often is based on unjust enrichment and seems to have used this solution in respect to work contracts. ${ }^{57}$

\section{B Legal Limits}

With a view to protecting persons who lack capacity, legislation limits restitution for cancellation on the grounds of incapacity. Adopting a moral tone, the courts have added a limit which results from the expressions nemo auditur propriam turpitudinem allegans and in pari causa turpitudinis cessat repetitio.

\section{The limits which relate to the protection of persons lacking capacity}

In terms of article 1312 of the Civil Code a person lacking capacity who in this capacity cancels a contract is bound to return only to the extent to which they have profited. That is to say the enrichment, to the exclusion of the sums or objects, which would have been received or lost (article 1241).

This is a strict rule for the person who contracts with a minor, who in addition must prove that the minor has been enriched. The case law balances the interests by interpreting in a broad way the notion of the enrichment that the person lacking capacity must return when this is used, for example, for paying a debt ${ }^{58}$ or in acquiring property even if that property is

56 En sa faveur Ghestin, Les obligations, Le contrat n 923; Mazeaud et Chabas, Obligations, $\mathrm{n}^{\circ}$ 332; Starck, Les obligations $\mathrm{n}^{\circ} 166$; Weill et Terré, Les obligations $\mathrm{n}^{\circ} 331$.

57 Soc 8 April 1957, D. 1958. 221 note Malaurie, Gaz Pal.1957.2.143; JCP 1958.II.10400, note B. P, and Soc. 9 March 1978 Bull civ V, n 178 p134 - 22 November 1979, ibid V, nº 885, p651; D. 1980.1.R.258; 3 October 1980, Bull civ V, n 704, p520; D. 1982.68, note Agostini, Rev trim dr. civ 1982.419, obs Chabas. Cass 15 February 1978 Bull civ V, n 107, p78; D. 1980.30, note G. Lyon-Caen, Gaz Pal. 1978.1. panorama 186).

58 Civ 23 February. 1891, D. 92.1. 29. 
immediately depreciated or lost by reason of force majeure. ${ }^{59}$ The burden of proof falls on the person seeking restitution. That person must prove that the sum claimed has effectively amounted to an enrichment for the person who lacks capacity. 60

\section{Limits imposed by penalising immorality}

The logical consequences of nullity can be upset when it is a penalty for the immorality of the contracting parties.

Restitution following the cancellation of an immoral contract (nullity for an immoral cause; immoral object; or as being contrary to good morals) can in fact be paralysed by the application of the rules nemo auditur and in pari causa which have the effect when an immoral contract is cancelled of obviating the need for return of the performances which have been made.

Although these rules established in the Ancien Droit are not found in the Civil Code, the case law uses them as a specific way of moralising contractual obligations. ${ }^{61}$

The immorality of a contract is penalised by absolute nullity. ${ }^{62}$ This result can be invoked by any interested person including the contracting party who is responsible for the immorality. The nemo auditur rule does not prevent the action for nullity. ${ }^{63}$ On this point the cases are difficult to rationalise and seem to compare the degree of turpitude of the parties, they are

59 There is an enrichment when the minor uses the money to good purpose, for example the payment of a debt, Cass Civ 23 February 1891: D. 1892. 1. 29: or where something is bought with the money from the contract, even if that thing is subsequently lost, Cass Req. 26 April 1900.

60 Cass req. 26 April 1900: D. 1900. 1. 455: S. 1901. 1. 93. note Ferron: 2 January 1901: D. 1901. 1. 16.

61 Caen, 29 July 1874: S. 1875. 2, 298. V H Roland et L Boyer. Adages du droit français (2 ed, 1986, L'Hermès).

62 Eg Cass Civ 1". 22 January 1975: Bull civ 1, nº 27.

63 Cass Civ Ir, 25 January 1972: D. 1972, 378. note le Tourneau: Cass Civ 3.8 January 1975: Bull civ 111. $\mathrm{n}^{\circ}$ 2: Cass Com Il May 1976: Bull civ IV, n 162: Cass Soc. 4 January 1979: Bull civ V, n 690; Cass Civ 3 ', 25 June 1985: D. 1986. 21. note Agostini. The maxim "In pari causa... " has been used to stop an action in guarantee between two parties who were morally to blame: Cass Com 27 April 1981: D. 1982. 51, note le Tourneau: Rev trim dr. civ 1982. 418. n², obs Durry. 
based in reality on the in pari causa rule. ${ }^{64}$ When the two parties have displayed an equal degree of moral turpitude the contract is cancelled and no restitution is possible.

Thus on the basis of these two principles whose respective areas of operation remain difficult to determine, an action for restitution has been refused to the purchaser of a brothel, 65 to a lender who provided the money for such a purchase, ${ }^{66}$ to the landlord of such a place, ${ }^{67}$ to a person who has agreed to lend to a married woman to enable her to join her lover, ${ }^{68}$ to a person who has lent to a gambler, ${ }^{69}$ to the lessor of a gambling establishment, ${ }^{70}$ and to a pimp who was ordered to reimburse to a prostitute the earnings that she had deposited with him. ${ }^{71}$ The same applies in the case of the cancelling of a contract, which has as its purpose the maintenance of a relationship of concubinage or adultery. ${ }^{72}$

64 C Cardahi "L'exécution des conventions immorales et illicites étude de l'adage « Nemo auditur... d'après le droit comparé, le droit musulman et les moralistes chrétiens" Rev int. dr. comp 1951. 385: Ph. Ie Tourneau. La règle « Nemo auditur... » préf. P Raynaud, (LGDJ 1970). Flour et Aubert, op cit., t.1, n 368 ,

65 Req. 17 July 1905, D. 1906.1.72; S. 909.1.188.

66 Each of the parties had an equal share in the contract; Req. 1 April 1895, D. 95.1.263; S. 96.1.289, note Rippert

67 Civ 15 November 1938, Gaz Pal. 1939.1.194, 27 December 1945, Gaz Pal. 1946.1.88; Civ lre, 15 February 1967, Bull civ I, nº 67, p 50

68 Req. 17 April 1923, D. 1923.1.172.

69 Crim. 19 November 1932, D.P 1933.1.26, note Capitant.

70 Pau, 28 June 1906, S. 1907.2.61; cpr. Aix, 14 May 1908, S. 1908.2.291 which did not admit the action for cancellation. Cpr. Ch. mixte 14 March 1980, Bull civ, Ch. mixte, n 3, p 3; D. 1980.1.R.336, obs Puech et 434, obs Cabrillac; Rev trim dr. civ 1980.764, note Chabas; Gaz Pal. 1980.1.290, concl. Robin, who does not allow the gaming exception to be pleaded against a claim by a casino against a gambler who issued a cheque without provision.

71 Crim. 7 June 1945, D. 1946.149, note R. Savatier; S. 1945.1.120; JCP 1946.1I.2955, note Hémard: a pimp was ordered to pay a prostitute the income from her prostitution by way of damages because "though art 1131 of the Civil Code declares that an obligation founded on an illicit cause has no effect, it does not address obligations such as here which derive from a criminal act for which the civil judgment provides compensation". Rouen, 2 October 1973, D. 1974.378, note Le Tourneau; less clearly Civ 25 January. 1972, D. 1972.413, note Le Tourneau.

72 Paris. I August 1903: D. 1904. 2. 345: Cass req. 17 April 1923: D. 1923. 1. 172: Trib. gr. inst. Paris. 4 Ch 22 May 1980: Gaz Pal. 1981. 1. somm. p 28. 
However, restitution is ordered if the immorality results from a breach of criminal law or if the petitioner appears to be the less guilty of the parties. ${ }^{73}$ Similarly, a chemist has been ordered to reimburse a sum received in advance for the making of a secret remedy, ${ }^{74}$ and a marriage broker was ordered to refund his commission in an era when such a contract was considered as contrary to good morals. ${ }^{75}$

Restitution is also sometimes ordered to satisfy a higher interest: a company which had entered into loans with a German bank in order to fulfil orders for military equipment was ordered to restore the sums in the context of liquidation of enemy properties "of which the net profit must flow to the Treasury" ${ }^{76}$

The case law does not apply to the nemo auditur rule except in the case of nullity for immorality. Restitution is therefore possible if the contract is cancelled for illegality. ${ }^{77}$

This distinction, however, does not rest on clear criteria and some decisions have refused restitution even in the case of the cancelling of an illegal contract. ${ }^{78}$

The application of the rule is equally ignored in the case of gifts; their cancellation is followed by restitution at common law. ${ }^{79}$

Finally, the courts will in each case consider the appropriateness of the nemo auditur rule thus creating a large degree of uncertainty about the consequences of the cancelling of an illegal or immoral contract.

73 Cass crim. 7 June 1945: D. 1946. 149, note R. Savatier: JCP 1946. II. 2955. note J. Hémard.

74 Besançon. 6 March 1895: D. 1895, 2. 223.

75 Cass req. 27 July 1897: S. 1897. 1. 522.

76 Cass Com 28 February 1967: Bull civ IV, nº 96 (first decision).

77 Cass Civ Ire. 19 December 1950: Bull civ 1. n 548: Colmar. 4 January 1961: Gaz Pal. 1961, 1. 304; Cass Civ 1. 15 June 1967: JCP 1967. II. 15238; Cass Com 27 April 1981: D. 1982, 51. note le Toumeau; 14 December 1982: Rev trim dr civ 1983. 342. n 2. obs Durry; 27 November 1984: D. 1986 448, note Penneau: Cass Civ 3, 25 June 1985: Bull civ 111. n 103 D. 1986. 212. note Agostini; Rev dr. immob. 1986, 216, obs Groslière et Saint-Alary-Houin: Cass Com 20 January 1987: JCP 1988, II. 20987. note Goubeaux.

78 Cass req. 6 January 1913: D.P 1914, 1, 13: concerning a contract that contravened the monopoly of money changers: Cass Civ 3. 12 June 1979: JCP 1981,II. 19494, note L. Boyer, denying restitution of rent paid in accordance with an illegal indexation clause, because the tenant had paid knowingly.

79 Cass Civ Ir, 25 January 1972: D. 1972. 413, note le Tourneau. 


\section{CONCLUSION}

French law has no general theory of restitution. The law of property, of contract, of delictual responsibility, of unjust enrichment, of the protection of those lacking capacity, can all be involved in various ways with the result that the case law remains hard to predict and varies according to the circumstances.

ÉLÉMENTS DE RÉFLEXION SUR LES CONSÉQUENCES ÉCONOMIQUES DE L'ANNULATION DU CONTRAT DANS LE DROIT FRANÇAIS

Qualifié par la doctrine de "contrat synallagmatique renversé", obligeant de restituer les prestations reçues, sur le principe, l'annulation du responsabilité délictuelle, de telle sorte que la jurisprudence reste aléatoire et fluctuante au gré contrat aboutit, en droit français à un anéantissement rétroactif des effets du contrat. Mais il reste que ce même droit, n'offre pas de théorie générale des restitutions, les solutions applicables empruntent tout autant au droit de

l'enrichissement sans cause qu'à celui des contrats et des biens ou encore de la des circonstances. 
(2000) 31 VUWLR 